\title{
MENGKAJI KEMBALI POSISI KORBAN KEJAHATAN DALAM SISTEM PERADILAN PIDANA
}

\author{
Rena Yulia* \\ Bagian Hukum Pidana \\ Fakultas Hukum Universitas Sultan Ageng Tirtayasa, Banten \\ Jalan Raya Jakarta Km 4 Pakupatan Kota Serang Banten, Jawa Barat
}

\section{Abstract}

Victims of crime is the one suffer either a bodily injury or a mental injury, or both of them in a crime. At the moment, the legal tratment of the victims of crime is not worth the legal treatment of the offender. The victims tend to be left behind in the law enforcement process as the victims cannot be directly involved in the judicial process to defent their rights. The state through the general prosecutor, took charge of such rights. The prosecution to represent the victims in the judicial process and provide protection interests of the victim.

Keywords: victims of crime, criminal justice system.

\section{Intisari}

Korban kejahatan merupakan pihak yang menderita kerugian baik secara fisik, psikis maupun materiil ketika terjadi sebuah kejahatan. Namun perlindungan hukum terhadap korban kejahatan tidak sebanding dengan perlindungan terhadap pelaku. Bahkan korban cenderung menjadi pihak yang terabaikan dalam proses penegakan hukum. Korban tidak dapat menjadi pihak sebagaimana pelaku. Korban tidak terlibat langsung dalam proses peradilan untuk membela hak-haknya. Negara mengambil sebagian hak korban untuk melakukan penuntutan, kemudian menugaskan jaksa penuntut umum untuk melakukan penuntutan. Dengan diserahkannya hak-hak korban dalam penuntutan maka penuntutan yang dilakukan harus melindungi kepentingan korban.

Kata Kunci: korban kejahatan, sistem peradilan pidana.

\section{Pokok Muatan}

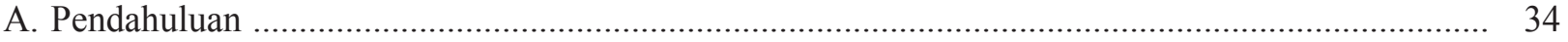

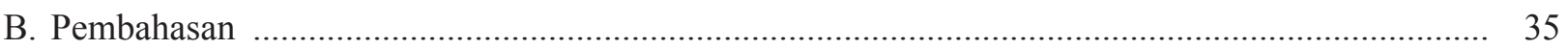

1. Hubungan antara Jaksa Penuntut Umum dengan Kepentingan Korban Kejahatan dalam Penuntutan Perkara Pidana ........................................................................................... 35

2. Melindungi Kepentingan Korban dalam Sistem Peradilan Pidana .......................................... 38

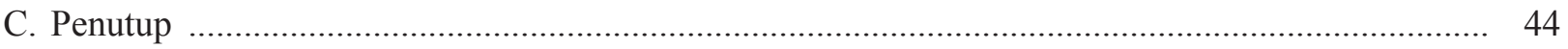




\section{A. Pendahuluan}

Bilamana kita lihat pada sejarah perkembangan hukum (hukum pidana), maka pada mulanya reaksi terhadap pelanggaran adalah sepenuhnya hak (dan kewajiban) korban. Akibat dari dendam (darah) yang sering tidak berkeputusan, telah timbul keadaan bahwa lambat laun "ganti rugi" oleh pelanggar dapat "dibayar dengan harta". Selanjutnya, dirasakan pula bahwa pelanggaran ini tidak hanya merupakan hubungan (urusan) pelaku dan korban. Pelaku pelanggaran dianggap juga mengganggu "keseimbangan" ketertiban dalam masyarakat, sehingga yang terjadi adalah juga gangguan dalam "keseimbangan" antara pelaku dan masyarakatnya. Rupanya, pada akhirnya gangguan yang terakhir inilah yang lebih diperhatikan sehingga masyarakat (negara) merasa sebagai satusatunya yang berhak untuk menuntut ganti rugi dari pelaku. Disini korban telah kehilangan haknya untuk mendapat pula ganti rugi. ${ }^{1}$

Dalam perkembangannya, pelanggaran hak yang dilakukan oleh seseorang tidak hanya berdampak kepada korban saja, melainkan berdampak pula kepada masyarakat luas. Dengan alasan itu, sehingga diperlukan adanya suatu institusi yang tampil sebagai pihak mewakili korban untuk melakukan penuntutan kepada pelaku. Hal ini dapat dilihat dalam penuntutan menurut sistem peradilan pidana di Indonesia yang menganut prinsip dominus litis yaitu hak monopoli negara. Sayangnya, pengambilalihan hak masyarakat oleh negara dalam perkembangannya lebih berorientasi kepada sistem pembalasan (retributive system), yang justru cenderung melupakan kepentingan korban. Akibatnya, peranan korban untuk menuntut hak-haknya mulai terabaikan. ${ }^{2}$
Negara telah mengambil alih peranan penuntutan dari korban dengan meminimalisir potensi pembalasan yang bersifat personal (emosional) dan untuk pemidanaan yang tepat atas dasar pertimbangan rasional (rasionalisasi) untuk korban dan masyarakat secara keseluruhan. ${ }^{3}$

Tidak dapat dipungkiri bahwa paradigma yang dibangun dalam sistem peradilan pidana saat ini menentukan bagaimana negara harus memainkan peranannya. Berdasarkan kewenangan yang dimilikinya, negara memiliki otoritas untuk mengatur warganegara melalui orang-orangnya. Dasar pandangan ini menempatkan negara sebagai pemegang hak menetapkan sejumlah norma yang berlaku dalam hukum pidana (ius punale) dan hak memidana (ius puniendi) sebagai bentuk penanganan suatu tindak pidana yang terjadi di dalam masyarakat. Namun demikian, penggunaan lembaga hukum pidana sebagai alat penanganan konflik menempatkan dirinya sebagai mekanisme terakhir dimana lembaga lain tidak dapat menjalankan fungsinya untuk menangani konflik yang terjadi (ultimum remedium). ${ }^{4}$

Implikasi dari pemikiran tersebut adalah pendefinisian kejahatan sebagai suatu serangan terhadap negara berdasarkan aturan perundangundangan yang dibuatnya sehingga kejahatan merupakan konflik antara pelaku kejahatan dengan negara. Atas dasar perlindungan kepada warga negara maka negara-lah yang berhadapan dengan pelaku kejahatan. Dari sinilah muncul posisi korban sebagai pihak yang pada dasarnya paling dirugikan terkait suatu tindak pidana kehilangan perannya. ${ }^{5}$

Hilangnya peran korban dalam sistem peradilan pidana didasarkan pada empat kelemahan yang dimilikinya saat ini, yaitu: ${ }^{6}$

\footnotetext{
Mardjono Reksodiputro, 2007, Kriminologi dan Sistem Peradilan Pidana, Pusat Pelayanan Keadilan dan Pengabdian Hukum, Jakarta, hlm. 75.

Heri Tahir, 2010, Proses Hukum yang Adil dalam Sistem Peradilan Pidana di Indonesia, Lakbang Pressindo, Yogyakarta, hlm. 184. Mudzakkir, "Perkembangan Viktimologi dan Hukum Pidana", Makalah, Pelatihan Hukum Pidana dan Kriminologi, Kerjasama FH UGM dan MAHUPIKI, University Club, Yogyakarta, 2014.

Eva Achjani Zulfa, "Restorative Justice dan Peradilan Pro-Korban”, dalam Adrianus Meliala, 2011, Reparasi dan Kompensasi Korban dalam Restorative Jusctice, Lembaga Perlindungan Saksi dan Korban dan Departemen Kriminologi FISIP UI, Jakarta, hlm. 27.

Ibid.

Ibid.
} 
a. Tindak pidana lebih diartikan sebagai penyerangan terhadap otoritas pemerintahan dibandingkan sebagai serangan kepada korban atau masyarakat;

b. Korban hanya menjadi bagian dari sistem pembuktian dan bukan sebagai pihak yang berkepentingan akan proses yang berlangsung;

c. Proses hanya difokuskan pada upaya penghukuman bagi pelaku dan pencegahan kejahatan semata tanpa melihat upaya perbaikan atas kerugian yang ditimbulkan dan mengembalikan keseimbangan dalam masyarakat;

d. Dalam penyelesaiannya, fokus perhatian hanya diarahkan kepada proses pembuktian atas kesalahan pelaku. Oleh karenanya, komunikasi hanya berlangsung satu arah yaitu antara hakim dan pelaku sementara konsep dialog utamanya yaitu antara pelaku dan korban tidak ada sama sekali.

Melihat hal yang demikian, dalam sistem peradilan pidana yang berlaku sekarang, dapat dimunculkan sebuah pemikiran bahwa hak-hak korban diambil alih oleh negara. Korban sebagai pihak yang langsung dirugikan kepentingannya, telah diwakili oleh Negara yang berperan sebagai pelaksana proses hukum dianggap tidak perlu lagi memiliki sejumlah hak yang memberikan perlindungan baginya dalam proses peradilan. ${ }^{7}$ Peranan korban dalam sistem peradilan pidana menjadi hilang. Kesempatan untuk menyampaikan keadilan yang diinginkan menjadi sempit. Satusatunya peluang yang dimiliki dalam konteks memperoleh keadilan korban adalah melalui kewenangan penuntut umum.

Jaksa penuntut umum dalam persidangan, melakukan penuntutan terhadap terdakwa atas perbuatannya yang telah merugikan korban tindak pidana. Oleh karenanya, peran jaksa tersebut pada hakikatnya adalah mewakili korban, walaupun dalam undang-undang kejaksaan secara jelas disebutkan mewakili negara. Tulisan ini ingin mengkaji kembali posisi korban dalam sistem peradilan pidana. Posisi dalam arti keterwakilan oleh subsistem peradilan, termasuk pengakuan akan hak-hak korban dalam sistem peradilan pidana.

\section{B. Pembahasan}

\section{Hubungan antara Jaksa Penuntut Umum dengan Kepentingan Korban Kejahatan dalam Penuntutan Perkara Pidana}

Lembaga penuntut umum seperti yang kita kenal sekarang berasal dari Perancis, yang akhirnya oleh negara-negara lain diambil alih dalam perundang-undangannya, juga oleh negeri Belanda yang memasukkan Wetbook van Strafvoerdering (Kitab Undang-undang Hukum Acara Pidana tahun 1838) serta dalam Indands Reglement tahun 1848, menerapkannya di Indonesia. ${ }^{8}$

Sejak masa-masa sewaktu belum ada suatu kekuasaan sentral yang menentukan sebagai kewajibannya untuk melaksanakan tugas-tugas peradilan, maka tidaklah banyak perbedaan antara pelaksanaan proses perdata dan proses pidana, juga dalam hal-hal untuk memperoleh putusan hakim agar terhadap seseorang dijatuhi pidana (tuntutan pidana) inisiatifnya adalah pada perseorangan, yaitu pada pihak yang dirugikan. ${ }^{9}$

Sistem ini lama kelamaan menunjukkan kekurangan-kekurangan yang menyolok. Penuntutan secara terbuka (accusatoir murni), dengan sendirinya telah menyebabkan penuntutan kesalahan seseorang menjadi lebih sulit, sebab yang bersangkutan segera akan mengetahui dalam keseluruhannya, semua hal yang memberatkan dirinya, sehingga dengan demikian ia akan memperoleh kesempatan untuk menghilangkan sebanyak mungkin bukti-bukti atas kesalahannya. ${ }^{10}$

Sifat perdata dari penuntutan tersebut menyebabkan pula bahwa seringkali sesuatu tuntutan pidana tidak dilakukan oleh orang yang dirugikan,

\footnotetext{
Weny Almoravid Dunga, "Implementasi Undang-Undang Perlindungan Saksi dan Korban di Gorontalo", Mimbar Hukum, Vol. 21, No. 2, Juni 2009.

Ansorie Sabuan, et al., 1990, Hukum Acara Pidana, Angkasa, Bandung, hlm. 119.

Ibid.

Ibid.
} 
karena ia takut terhadap pembalasan dendam atau ia tidak mampu untuk mengungkapkan kebenaran dari tuntutannya, sebab kekurangan alat-alat pembuktian yang diperlukan. Dengan demikian banyaklah pembuat tindak pidana yang sebenarnya terang bersalah tidak dapat dijatuhi pidana. ${ }^{11}$

Atas dasar alasan-alasan tersebut di atas maka pemerintah yang bertanggungjawab terhadap pembinaan peradilan yang baik, telah mengambil alih inisiatif tuntutan pidana tersebut dari perseorangan, dan menyerahkan kepada suatu badan negara yang khusus diadakan untuk itu ialah Openbaar Ministerie atau Openbaar Aanklager, yang kita kenal sebagai penuntut umum. ${ }^{12}$

Sejak saat itu suatu tindak pidana yang merugikan kepentingan anggota masyarakat, akhirnya dianggap sebagai suatu perbuatan yang melanggar kepentingan pribadi seseorang saja. Tuntutan pidana bukanlah soal pribadi lagi, tetapi adalah persoalan kepentingan umum dan oleh karena itu segala penuntutan pidana haruslah pemerintah yang melakukan atas nama masyarakat. Sejak itu penuntut umum atas nama pemerintah yang menuntut semua pelanggaran undang-undang di muka pengadilan, dan setelah hakim menjatuhkan putusan, ia pulalah yang menjalankan eksekusi putusan tersebut. ${ }^{13}$

Hakim menjatuhkan putusan tentu juga harus memperhatikan kepentingan umum, masyarakat atau pun kepentingan pihak yang dirugikan. Dalam praktek, Hakim mengambil keputusan menggunakan penafsiran. Penafsiran dilakukan dengan menggunakan teori. Salah satu teorinya adalah $D e$ Schutznorm Theori.

Secara ringkas teori schutznorm dapat dikatakan bahwa meskipun menimbulkan perbuatan melawan hukum dari seseorang menimbulkan kerugian pada orang lain, orang yang melakukan perbuatan melawan hukum itu hanya diwajibkan untuk mengganti kerugian apabila norma yang dilanggar khusus ditujukan untuk melindungi kepentingan hukum orang lain yang terlanggar. ${ }^{14}$

Teori ini berasal dari Jerman yang dapat dilihat dari Pasal 823 BGB ayat 2 yang artinya kewajibankewajiban yang sama (yakni ganti rugi) kena kepada mereka, yang perbuatannya bertentangan dengan hukum yang bertujuan melindungi kepentingan hukum orang lain. ${ }^{15}$

Menurut pendukung teori ini, disamping adanya hubungan causal antara perbuatan dan kerugian, juga harus ada hubungan causal lain, yaitu antara sifat melawan hukum dari perbuatan dan kerugian. ${ }^{16}$

Tetapi menurut Rutten: hubungan yang disebut terakhir ini bukan hubungan sebab-akibat, sebab sifat melawan hukum bukan fakta tetapi suatu kualifikasi. Telders menyebut hubungan ini suatu hubungan normatif. Mungkin lebih jelas dan lebih benar apabila orang mengatakan bahwa dituntut suatu hubungan antara norma yang dilanggar dengan kepentingan yang dilanggar. ${ }^{17}$

Dalam bidang hukum pidana, apabila terjadi suatu perbuatan melawan melawan hukum, dua kutub yang saling berhadapan adalah jaksa yang bertindak untuk dan atas nama negara serta mewakili kepentingan korban di satu pihak, dengan terdakwa atau terdakwa-terdakwa yang dituduh melakukan perbuatan melawan hukum tadi di pihak lain. ${ }^{18}$

Disinilah letak pentingnya pembatasan kekuasaan para penegak hukum, karena pada tangan mereka (polisi, jaksa, dan hakim) terletak kekuasaan negara untuk menuntut, menyidik, dan memutuskan suatu pemidanaan. ${ }^{19}$ Dalam rangka toeri Schutznorm ini, timbul pertanyaan: kepentingan hukum apakah yang hendak dilindungi oleh hukum pidana?

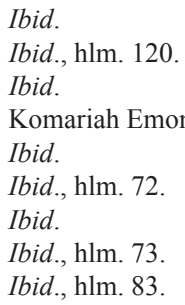


Machielse, dalam suatu catatan tentang kepentingan hukum, yang mengulang kembali pada sejarah pengertian hukum, menyatakan: bahwa dinamika dalam perkembangan pemikiran yang dinamis tentang kepentingan hukum berhubungan erat dengan penilaian yang berubah-ubah yang dipertemukan oleh kedua fungsi kepentingan hukum itu dalam tahun-tahun sebelumnya, yakni fungsi legitimasi dan fungsi interpretatif. Fungsi yang melegitimasi berisikan bahwa pemerintah baru boleh bertindak terhadap kebebasan warga jika dengan tindakan itu akan melindungi kepentingan hukumnya. Fungsi interpretatif berisikan bahwa dalam kepentingan hukum terdapat faktor penting dengan penetapannya dalam undang-undang. ${ }^{20}$

Kepentingan hukum menurut Feuerbach adalah kebebasan sebagai harkat tertinggi dari individu harus menemukan pembatasannya dalam kebebasan individu yang lain, dan negara harus menjaga kebebasan semua orang. Negara harus menjamin perlindungan kebebasan dan hak-hak yang muncul dari kebebasan itu tidak lagi sebagai penjelmaan dari suatu kemauan metafisis, bersifat Ketuhanan dan di luar sifat-sifat manusia, tetapi sebagai penjelmaan dari kemauan bersama atau dari suatu kewajiban etis yang paling tinggi. ${ }^{21}$

Masih dalam buku Komariah Emong, dikutip pula Birnbaum yang menyatakan bahwa bukan suatu hak subjektif, tetapi objek hukum, kepentingan hukum yang dilanggar oleh tindak pidana. Objek tindak pidana tidak terletak pada sesuatu yang ditemukan secara rasional, melainkan pada sesuatu yang diciptakan oleh penilaian. ${ }^{22}$

Binding mengatakan semua kepentingan hukum mempunyai nilai sosial, tetapi tidak dapat dipungkiri bahwa individu mempunyai kepentingan langsung terhadap benda-benda hukum itu. Selanjutnya dikatakan bahwa kebebasan, hidup, kehormatan, menurut urut-urutannya jauh lebih penting disamping perasaan (rasa hormat terhadap Tuhan, dan rasa kasih sayang terhadap binatang), di samping kepentingan hukum dari negara dan bangsa, dan di samping kepentingan hukum yang lebih banyak mengandung isi sosial kolektif). ${ }^{23}$

Dengan demikian jelaslah bahwa bukan hakhak alamiah individu yang dilindungi oleh undangundang pidana, melainkan apa yang dianggap pantas dilindungi oleh pembuat undang-undang dan terhadap pilihan pembuat undang-undang tersebut kita harus menghormatinya. ${ }^{24}$

Pengertian kepentingan hukum menurut Von List adalah pengertian yang ada dalam perbatasan antara formal logis dari ilmu hukum dan ilmu kemasyarakatan. Karena itu menurut Von List, suatu kepentingan hukum adalah suatu kepentingan hidup, ini berarti bahwa suatu kepentingan tidak dibuat oleh hukum, tetapi oleh kehidupan itu sendiri. ${ }^{25}$

Perkembangan terakhir arti kepentingan hukum ini dikemukakan secara teologis. Menurut teori ini, yang dikemukakan oleh Max Grunhut, Schwinge, dan Zimmert, serta merupakan eksponen ajaran yang mengatakan bahwa peranan kepentingan hukum adalah karena pencantumannya secara terbatas dalam undang-undang. Kepentingan hukum untuknya bukan sesuatu potongan yang ada pada kenyataan, yang akan dapat dirusak, dan yang pantas mendapatkan perlindungan dari pembuat undang-undang; kepentingan hukum berarti tidak lain dari tujuan undang-undang sebagai ungkapan keinginan negara, dan disimpulkan bahwa pembuat undang-undang mempunyai otonomi sepenuhnya untuk membuat ketentuan-ketentuannya. Cabang dari ilmu hukum pidana adalah mencari tujuan satusatunya dari hukum pidana. ${ }^{26}$

Tentang letak kepentingan hukum yang akan dilindungi ini, yang dikatakan oleh teori-teori tersebut di atas adalah bahwa harus jelas terlihat

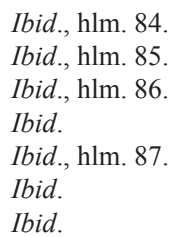


dalam perumusan undang-undang, bagi undangundang pidana menimbulkan akibat yang sangat penting artinya karena akan menimbulkan persoalan bagi penentuan sifat melawan hukumnya. ${ }^{27}$

Persoalan ini akan menimbulkan dua model perumusan delik yang menyebabkan implikasi dari akibat-akibatnya. Model pertama ialah apabila kepentingan hukum yang dilindungi itu harus secara tegas dicantumkan dalam perumusan undangundang, alasan-alasan pembenarnya, apabila terjadi pelanggaran terhadap kepentingan hukum ini, juga harus secara jelas dimuat dalam ketentuan undangundang yang bersangkutan, setidak-tidaknya secara terpisah. Model kedua apabila kepentingan hukum yang hendak dilindungi ini hanya secara eksplisit saja, maka hal tersebut setidak-tidaknya dapat dimuat dalam bagian umum (algemene deel) dari undang-undang tersebut. ${ }^{28}$

Heijder dan Scaffmeister mengatakan suatu perbuatan yang tidak dilindungi oleh norma kepentingan hukum yang dilanggar berada di luar perumusan delik, akan berarti juga tidak memenuhi sifat melawan hukum dari segi hukum pidananya, yang menurut catatan Remmelink merupakan jalan keluar penerapan teori Schutznorm dalam hukum pidana. $^{29}$

\section{Melindungi Kepentingan Korban dalam Sistem Peradilan Pidana}

Pada waktu korban masih berhak menuntut pembalasan atau ganti rugi terhadap atau dari pelaku pelanggaran, maka peranan atau sumbangan korban dalam terjadinya pelanggaran wajib diperhatikan dan menentukan besar-kecilnya pembalasan atau ganti rugi itu. Setelah segala balas dendam dan ganti rugi ini menjadi sepenuhnya hak negara, maka peranan korban dalam terjadinya pelanggaran tidak diperhatikan lagi. Malahan mereka yang kini berusaha membela nasib korban (antara lain dengan memperjuangkan ganti rugi melalui prosedur perdata) juga melupakan peranan korban ini. Juga perkembangan pemikiran tentang tujuan pidana, yang antara lain didasarkan kepada perlunya pembinaan si pelaku (terpidana) agar dapat kembali ke masyarakat, menurut Shafer, telah dibarengi dengan kenyataan sangat berkurangnya perhatian kepada korban. Dan kalaupun ada perhatian terhadap korban, hal itu dianggap tidak boleh menghalangi pembinaan si pelaku/terpidana. ${ }^{30}$

Dari uraian singkat di atas, ada dua hal: ${ }^{31}$

a. Bahwa untuk si korban, perlu dipikirkan dan diberikan perhatian kepada penderitaan yang dialaminya karena terjadinya delik itu; dan

b. Bahwa untuk si pelaku delik, perlu diketahui bagaimana peranan korban dalam terjadinya delik, maupun keadaan kejahatan pada umumnya.

Pemikiran dari poin a akan mempunyai pengaruhnya pada (ilmu) hukum pidana dan proses peradilan pidana. Kalau benar dapat ditunjukkan bahwa sistem peradilan pidana sekarang ini tidak/ kurang memberi kepuasan kepada korban, dalam arti tidak/kurang memberi perhatian kepada kepentingannya yang dilanggar (dirugikan), maka mungkin diperlukan suatu pembaharuan yang mendalam tentang hal ini. Hulsman, menganjurkan pemikiran ini, khusus untuk bidang yang menyangkut delik dimana dapat ditunjuk adanya korban individual (perseorangan). Dalam konteks Indonesia, dimana KUHP dan ilmu hukum pidana itu didasari pemikiran Barat, perlu digali bagaimana pemikiran hukum adat (adat delicten recht) dapat menyumbang ke arah ini. ${ }^{32}$

Sedangkan hasil pemikiran tentang poin $b$ akan banyak membantu pengembangan pikiran dalam kriminologi. Antara lain Nagel (dengan relatie-criminologienya) dan Shafer (dengan konsep tanggungjawab fungsionalnya) patut diperhatikan

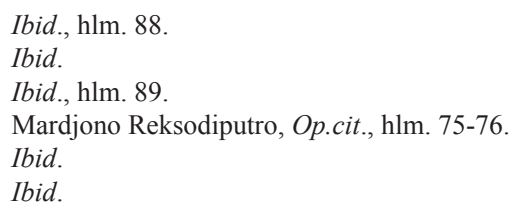


dalam hal ini. Dengan lebih mengetahui peranan korban dalam terjadinya delik, maka badan penegak hukum juga akan banyak dapat menarik manfaat darinya, khususnya dalam kegiatan dan usaha pencegahan. Dalam rangka pengetahuan tentang keadaan kejahatan pada umumnya, suatu survei tentang korban akan dapat pula menambah pengertian kita tentang hidden criminality (kejahatan yang tersembunyi). ${ }^{33}$

Muladi mengemukakan beberapa alasan yang bertalian dengan perlindungan korban yaitu: Pertama, proses pemidanaan dalam hal ini mengandung pengertian, baik dalam arti umum maupun dalam arti konkret. Dalam arti umum menurut Muladi, proses pemidanaan merupakan wewenang pembuat undang-undang, sesuai dengan asas legalitas, yang menegaskan bahwa baik poena maupun crimen harus diterapkan terlebih dahulu apabila hendak menjatuhkan pidana atas diri seseorang pelaku tindak pidana. Sedangkan dalam arti konkret, proses pemidanaan berkaitan dengan penetapan pidana melalui infrastruktur penitensier (hakim, petugas lembaga pemasyarakatan dan sebagainya). Di sini, lanjut Muladi, terkandung di dalamnya tuntutan moral, dalam wujud keterikatan filosofis pada satu pihak dan keterkaitan sosiologis dalam kerangka hubungan antar manusia dalam masyarakat pada lain pihak. ${ }^{34}$

Lebih lanjut menurut Muladi, secara sosiologis semua warga negara harus berpartisipasi penuh di dalam kehidupan kemasyarakatan, masyarakat dianggap sebagai suatu wujud sistem kepercayaan yang melembaga (system of institutionalized trust). Tanpa kepercayaan ini, kehidupan sosial tidak mungkin berjalan dengan baik, sebab tidak ada pedoman atau patokan yang pasti dalam bertingkah laku. Kepercayaan ini terpadu melalui norma-norma yang diekspresikan di dalam struktur kelembagaan (organisional) seperti: kepolisian, kejaksaan, pengadilan, lembaga koreksi dan sebagainya. Terjadinya kejahatan atas diri korban, akan bermakna menghancurkan sistem kepercayaan tersebut, pengaturan hukum pidana dan hukum lain yang menyangkut masalah korban, berfungsi sebagai pengembalian sistem kepercayaan tersebut. ${ }^{35}$

Kedua, bertolak dari argumentasi lain yang mengedepankan perlindungan hukum bagi korban kejahatan adalah argumen kontrak sosial dan argumen solidaritas sosial. Negara lebih boleh dikatakan monopoli seluruh reaksi sosial terhadap kejahatan dan melarang tindakan yang bersifat pribadi. Oleh karena itu, bila terjadi kejahatan dan menimbulkan korban, negara harus bertanggungjawab untuk memperhatikan kebutuhan para korban tersebut. Sementara, yang disebut terakhir, menyatakan bahwa negara harus menjaga warga negaranya dalam memenuhi kebutuhannya atau apabila warga negaranya mengalami kesulitan, melalui kerjasama dalam masyarakat berdasarkan atau menggunakan sarana-sarana yang disediakan oleh negara. Hal ini bisa dilakukan baik melalui peningkatan pelayanan maupun melalui pengaturan hak. $^{36}$

Ketiga, Muladi memandang bahwa masalah pengaturan korban kejahatan biasanya dikaitkan dengan salah satu tujuan pemidanaan, yang dewasa ini banyak dikedepankan yakni penyelesaian konflik. Penyelesaian konflik yang ditimbulkan oleh adanya tindak pidana, memulihkan keseimbangan dan mendatangkan rasa damai dalam masyarakat. ${ }^{37}$

Bila menyimak sejarah perkembangan penologi, tampak bahwa reaksi kepada pelaku kejahatan sepenuhnya merupakan hak para korban. Setiap orang (korban) yang merasa dilanggar hakhaknya berhak untuk melakukan pembalasan secara langsung kepada yang melakukan pelanggaran atas dirinya. Bahkan kalau mampu, mereka bisa melakukan tindakan yang lebih dahsyat daripada yang dialaminya. Pada masa ini lebih banyak diwarnai oleh balas dendam secara fisik. Namun,

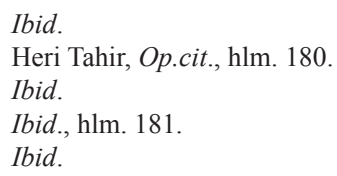


lambat laun, muncul kesadaran masyarakat untuk mengganti balas dendam fisik ini berupa pemberian santunan atau ganti rugi oleh pelaku ke pihak korban. ${ }^{38}$

Kehadiran restorative justice pada dasarnya menjadi kunci pembuka pemikiran kembali tentang posisi korban dalam suatu penyelesaian perkara pidana. Penanganan perkara pidana dengan pendekatan keadilan restoratif menawarkan pandangan dan pendekatan berbeda dalam memahami dan menangani suatu tindak pidana. Dalam pandangan restorative justice makna tindak pidana pada dasarnya sama seperti pandangan hukum pidana pada umumnya. Akan tetapi, dalam pendekatan keadilan restoratif ini, korban utama atas terjadinya suatu tindak pidana bukanlah negara, sebagaimana dalam sistem peradilan pidana yang sekarang ada. Oleh karenanya kejahatan menciptakan kewajiban untuk membenahi rusaknya hubungan akibat terjadinya suatu tindak pidana. ${ }^{39}$

Sementara itu, keadilan dimaknai sebagai proses pencarian pemecahan masalah yang terjadi atas suatu perkara pidana dimana keterlibatan korban, masyarakat dan pelaku menjadi penting dalam usaha perbaikan, rekonsiliasi dan penjaminan keberlangsungan usaha perbaikan tersebut. Hegel menyatakan bahwa hukuman merupakan relationship between criminal and victim. Oleh karenanya, berbeda dengan sistem peradilan pidana konvensional, dengan memanfaatkan pendekatan restorative justice maka: ${ }^{40}$

a. Korban menjadi pihak yang berada dalam posisi sentral dari proses;

b. Fokus dari proses adalah untuk memulihkan dampak dari tindak pidana yang timbul dan dialami korban dan pelaku atau kalau mungkin terhadap masyarakat luas;

c. Anggota masyarakat atau NGO dapat mengambil bagian dari proses secara aktif; dan

d. Karakteristik dari proses yang berlangsung merupakan suatu dialog dan negosiasi antara para pihak.

Restorative justice diajukan oleh kaum abolisionis yang melakukan penolakan terhadap sarana koersif yang berupa sarana penal yang diganti dengan sarana reparatif. Untuk mencapai tujuan yang dimaksudkan maka dibutuhkan usaha-usaha yang kooperatif dari komunitas dan pemerintah untuk menciptakan sebuah kondisi dimana korban dan pelaku dapat merekonsiliasi konflik mereka dan memperbaiki luka-luka mereka. Restorative justice mengupayakan untuk me-restore keamanan korban, penghormatan pribadi, martabat, dan yang lebih penting adalah sense of control. ${ }^{41}$

Ada beberapa prinsip dasar yang menonjol dari restorative justice terkait hubungan antara kejahatan, pelaku, korban, masyarakat dan Negara. Pertama, kejahatan ditempatkan sebagai gejala yang menjadi bagian tindakan sosial dan bukan sekedar pelanggaran hukum pidana; Kedua, restorative justice adalah teori peradilan pidana yang fokusnya pada pandangan yang melihat bahwa kejahatan adalah sebagai tindakan oleh pelaku terhadap orang lain atau masyarakat daripada terhadap Negara. Jadi lebih menekankan bagaimana hubungan/tanggungjawab pelaku atau individu dalam menyelesaikan masalahnya dengan korban dan atau masyarakat; Ketiga, kejahatan dipandang sebagai tindakan yang merugikan orang dan merusak hubungan sosial. Ini jelas berbeda dengan hukum pidana yang telah menarik kejahatan sebagai masalah Negara, hanya Negara yang berhak menghukum; dan Keempat, munculnya ide restorative justice sebagai kritik atas penerapan sistem peradilan pidana dengan pemenjaraan yang dianggap tidak efektif menyelesaikan konflik sosial. $^{42}$

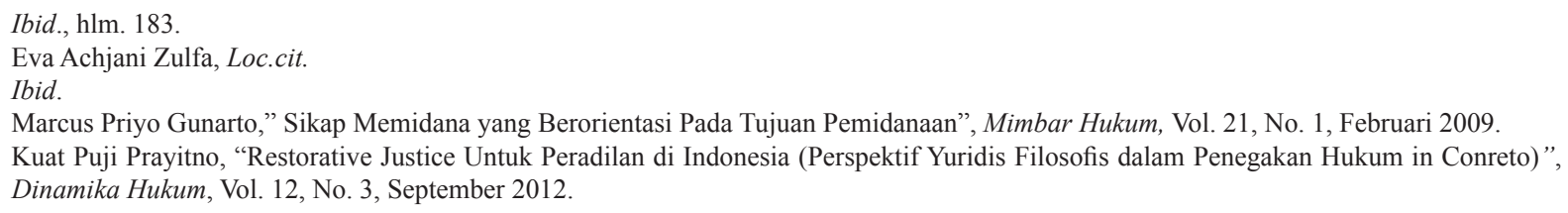


Keadilan dalam restorative justice mengharuskan untuk adanya upaya pemulihan/mengembalikan kerugian atau akibat yang ditimbulkan oleh tindak pidana, dan pelaku dalam hal ini diberi kesempatan untuk dilibatkan dalam upaya pemulihan tersebut. Semua itu dalam rangka memelihara ketertiban masyarakat dan memelihara perdamaian yang adil. ${ }^{43}$

Dalam hubungannya antara pelaku kejahatan dengan korbannya, sistem hukum yang berlaku (KUHAP) sekarang kurang peduli terhadap kepentingan korban. Kehadiran korban dan saksi dalam proses peradilan pidana selain tidak diberi kompensasi karena mereka meninggalkan pekerjaan dan membutuhkan biaya menuju ke tempat sidang, perlindungan keselamatan dari gangguan pelaku dan kelompoknya juga tidak dijamin. Kini dalam kehidupan praktis dunia hukum, yang sebelumnya tidak memberi tempat pada korban kejahatan dalam hukum, dengan perkembangan penelitian viktimologi mulai mendapat perhatian. ${ }^{44}$

Proses penegakan hukum yang dilakukan akan memberikan fokus hukuman kepada pelaku dengan tetap mengakomodasi hak-hak dan kepentingan korban. Jaksa penuntut umum dalam hal ini, memposisikan diri sebagai korban, sehingga dapat memahami dan mengerti kepentingan apa yang harus diperoleh korban melalui proses penegakan hukum tersebut. Jaksa akan menjaga agar proses penegakan hukum yang berlangsung tidak saja adil bagi pelaku kejahatan melainkan juga adil bagi korban yang notabene dirugikan akibat kejahatan tersebut.

Terkait dengan kepentingan hukum korban kejahatan dalam sistem peradilan pidana, maka diperlukan sebuah peran jaksa dalam mengedepankan kepentingan tersebut. Hal ini sudah tertuang dalam Surat Petunjuk Jaksa Agung No. B-63/E/2/1994 tentang Perlindungan Terhadap Korban Kejahatan. Dalam instruksi tersebut disebutkan bahwa kerugian yang diderita oleh pihak lain adalah termasuk kerugian korban. Hal ini merujuk pada Pasal 98 KUHAP. Surat Petunjuk tersebut berisi sebagai berikut:

a. Agar memanfaatkan pasal 98 KUHAP dalam memberikan perlindungan terhadap kepentingan korban kejahatan, dengan berusaha menggabungkan gugatan ganti kerugian yang diajukan oleh korban kejahatan dengan perkara pidananya.

b. Kepada korban kejahatan atau keluarganya sejak dini diberikan informasi mengenai haknya untuk mengajukan gugatan ganti rugi kepada pelaku kejahatan.

c. Dilakukan pendekatan dengan hakim agar diperoleh persepsi yang sama.

d. Barang bukti yang menjadi alat mata pencaharian korban kejahatan atau keluarganya, misalnya kendaraan dan sebagainya dapat dipertimbangkan untuk dipinjam-pakai oleh korban atau keluarganya.

e. Ditempuh usaha lain yang pada prinsipnya dapat membantu korban kejahatan yang diharapkan berdampak positif pada meningkatnya peran serta masyarakat (khususnya korban kejahatan) dalam penegakan hukum, misalnya terdorong untuk segera melaporkan setiap tindak pidana yang terjadi, bersedia menjadi saksi atau berperan serta dalam upaya mencegah terjadinya kejahatan.

Surat petunjuk di atas kemudian dikuatkan dengan petunjuk Nomor: B-187/E/5/3/95 perihal Perlindungan Terhadap Korban Kejahatan ${ }^{45}$. Petunjuk tersebut berisi sebagai berikut:

a. Supaya sejak tahap pra penuntutan Jaksa Penuntut Umum sudah memberitahukan kepada korban kejahatan baik anggota masyarakat maupun Negara c.q. Instansi/lembaga terkait mengenai hak-haknya untuk menga-

44 Muhammad Mustofa, "Kehadiran Negara dalam Perlindungan Saksi dan Korban Kejahatan”, Jurnal Perlindungan, Edisi III, Vol. 1, Tahun 2013.

45 Rena Yulia, "Melihat Kembali Keberadaan Korban Kejahatan dalam Sistem Peradilan Pidana (Sebuah Upaya Pemenuhan Hak Korban oleh Jaksa Penuntut Umum)", dalam Syaiful Bakhri, et al., 2014, Hukum Pidana Masa Kini, Mahupiki dan Total Media, Yogyakarta, hlm. $176-177$. 
jukan gugatan ganti kerugian yang bersifat materil yang dideritanya sebelum tuntutan pidana dibacakan sesuai pasal 98 KUHAP. Sedangkan kerugian lainnya dapat diajukan melalui proses perdata sebagaimana dijelaskan dalam Bab IV Keputusan Menteri Kehakiman RI Nomor: M.01/ PW.07.03 tahun 1982.

b. Dalam hal terhadap terdakwa patut dituntut dengan hukuman percobaan agar diterapkan ketentuan pasal $14 \mathrm{c}$ KUHP dengan mencantumkan kewajiban membayar ganti kerugian kepada korban kejahatan sebagai syarat khusus.

c. Dalam hal dituntut hukuman bukan percobaan diharapkan Jaksa Penuntut Umum mengadakan pendekatan kepada Hakim untuk kemungkinan mengembangkan yurisprudensi dengan menjatuhkan hukuman tambahan terhadap terdakwa membayar ganti rugi kepada korban kejahatan.

d. Mengusahakan upaya-upaya lain yang dapat membantu pemulihan kerugian yang diderita korban kejahatan baik material maupun immaterial dengan melibatkan badan-badan sosial baik yang dibentuk atas prakarsa masyarakat maupun atas dorongan pemerintah.

e. Petunjuk ini merupakan penegasan dan melengkapi Petunjuk kami Nomor B-63/E/2/94 tanggal 4 Februari 1994, perihal Perlindungan Terhadap Korban Kejahatan.

Petunjuk tersebut apabila diimplementasikan dalam praktek peradilan tentu akan memberikan jaminan terhadap perlindungan hak-hak dan kepentingan korban kejahatan. Khususnya dalam penggabungan gugatan ganti kerugian. Jaksa akan membangun komunikasi hukum dengan korban tentang kerugian material yang diderita sebagai akibat korban tindak pidana. Dakwaan yang dibuat tentu akan mempertimbangkan kerugian korban. Kemudian tuntutan yang diajukan akan memuat penghukuman terhadap pelaku dan pengajuan pemulihan hak-hak korban melalui pembayaran ganti kerugian. ${ }^{46}$

Proses pengajuan kompensasi, restitusi, dan ganti kerugian tentu yang memegang peranan utama adalah pihak kejaksaan. Dalam wewenangnya melakukan penuntutan, hak-hak korban untuk memperoleh kompensasi, restitusi ataupun ganti kerugian dapat langsung terakomodasi. Dengan begitu jaksa dapat melindungi hak-hak korban dalam memperoleh kompensasi, restitusi atau pun ganti kerugian. ${ }^{47}$

Akan tetapi pada kenyataannya pengaturan mengenai penggabungan gugatan ganti kerugian atau pun restitusi bagi korban tindak pidana yang telah diatur dalam Pasal 98 KUHAP tersebut, meski sudah dilengkapi dengan peraturan kejaksaan, pasal ini jarang dipakai. Demikian juga peraturan yang ada di dalam KUHP maupun UU Nomor 13 Tahun 2006 tentang Perlindungan Saksi dan Korban yang telah dilengkapi dengan PP Nomor 44 Tahun 2008 tidak mudah untuk diterapkan dalam proses penegakan hukum. ${ }^{48}$

Rancangan KUHAP tahun 2015 pun tidak lagi diatur mengenai penggabungan gugatan ganti kerugian sebagaimana yang ada dalam KUHAP. Hal ini memberikan batasan bagi korban dalam mengajukan upaya memperoleh ganti rugi dari kerugian yang diderita sebagai korban tindak pidana.

Padahal mekanisme penggabungan gugatan ganti kerugian merupakan sistem khas Indonesia yang tidak ada di negara lain. Walaupun memang dalam prakteknya jarang sekali digunakan sehingga seolah-olah tidak efektif, tetapi jika diterapkan dengan semestinya maka mekanisme penggabungan gugatan ganti kerugian dapat memulihkan kerugian korban secara dini dengan tidak menghapuskan hukuman sehingga pelaku tetap memperoleh efek jera dari hukuman tersebut. Malah kemungkinan efek jera nya akan menjadi berlipat, selain harus 
membayar sejumlah kerugian pelaku, juga tetap harus menjalani hukuman. Bagi korban keuntungan yang diperoleh adalah penggantian kerugian yang diderita akan lebih cepat dapat diterima dibanding harus mengajukan gugatan perdata setelah perkara pidananya selesai.

Tidak diaturnya pasal mengenai penggabungan gugatan ganti kerugian dalam Rancangan KUHAP tersebut membatasi kesempatan korban kejahatan untuk memiliki peran dalam mengajukan gugatan kerugian dalam proses peradilan pidana. Namun ada kesempatan korban untuk memperoleh kompensasi dari kerugian yang diderita yaitu terdapat dalam Bab XI tentang Ganti Kerugian, Rehabilitasi, dan Putusan Pengadilan Tentang Ganti Kerugian Terhadap Korban. Terkait dengan korban kejahatan terdapat dalam bagian ketiga Pasal 133 Rancangan KUHAP tahun 2015 yang menyebutkan bahwa:

(1) Apabila terdakwa dijatuhi pidana dan terdapat korban yang menderita kerugian material akibat tindak pidana yang dilakukan oleh terdakwa, hakim mengharuskan terpidana membayar ganti kerugian kepada korban yang besarnya ditentukan dalam putusannya.

(2) Apabila terpidana tidak membayar ganti kerugian sebagaimana dimaksud pada ayat (1), harta benda terpidana disita dan dilelang untuk membayar ganti kerugian kepada korban.

(3) Apabila terpidana berupaya menghindar untuk membayar kompensasi kepada korban, terpidana tidak berhak mendapatkan pengurangan masa pidana dan tidak mendapatkan pembebasan bersyarat.

(4) Dalam penjatuhan pidana bersyarat dapat ditentukan syarat khusus berupa kewajiban terpidana untuk membayar ganti kerugian kepada korban.

(5) Ketentuan lebih lanjut mengenai syarat dan tata cara penyitaan dan pelelangan sebagaimana dimaksud pada ayat (2) diatur dengan Peraturan Pemerintah.

Korban kejahatan dapat memperoleh ganti kerugian berdasarkan putusan pengadilan. Kerugian yang diganti adalah kerugian material dan dibayarkan oleh pelaku tindak pidana berdasarkan putusan hakim. Apabila terpidana tidak membayar maka harta bendanya akan disita untuk membayar sejumlah kerugian yang diputuskan tersebut.

Upaya terpidana untuk menghindar dalam membayar kompensasi akan berakibat tidak adanya pengurangan masa hukuman dan terpidana tidak akan memperoleh pembebasan bersyarat. Dalam penjatuhan pidana bersyarat dapat ditentukan syarat khusus berupa kewajiban terpidana untuk membayar ganti kerugian kepada korban.

Pasal 133 RUU KUHAP menjelaskan bahwa terpidana yang mampu membayar ganti kerugian tidak pantas mendapatkan pidana yang lebih ringan dibandingkan dengan orang yang tidak mampu sebab ia memiliki uang untuk membayar kompensasi.

Proses atau pun tata cara penggantian kerugian ini akan ditentukan oleh Peraturan Pemerintah. Dalam kenyataannya yang ada sekarang, Peraturan pemerintah mengenai pemberian kompensasi, restitusi, dan bantuan kepada saksi dan korban telah diatur dalam Peraturan Pemerintah Nomor 44 Tahun 2008. Namun pada prakteknya memerlukan peran Lembaga Perlindungan Saksi dan Korban (LPSK). Namun perlu diingat bahwa LPSK sendiri kedudukannya di luar sistem peradilan pidana.

Hal itu tentu akan menambah panjang prosedur pemenuhan ganti rugi bagi korban. Oleh karenanya, memaksimalkan peran jaksa untuk tetap dapat mengembalikan kepentingan korban melalui sistem peradilan pidana harus mendapat perhatian kembali. Posisi jaksa sebagai penuntut umum yang melakukan penuntutan terhadap terdakwa tentu dapat dianggap dengan memihak kepentingan korban. Sehingga penuntutan yang dilakukan merupakan upaya pemenuhan kepentingan korban.

Ketentuan tentang kompensasi bagi korban yang diputuskan oleh pengadilan dalam Rancangan KUHAP tersebut sebetulnya memberikan ruang kepada jaksa penuntut umum untuk mengajukan tuntutan mengenai pemulihan ganti kerugian berdasarkan kerugian yang diderita. Tuntutan 
ganti kerugian tersebut dapat disatukan dengan tuntutan pidana yang diajukan kepada terdakwa. Sehingga nanti hakim akan mengabulkan tuntutan ganti kerugian tersebut berdasarkan kerugian yang diderita oleh korban yang diajukan oleh jaksa penuntut umum.

Untuk menentukan jumlah kerugian yang diderita, tentu jaksa penuntut umum harus melakukan komunikasi hukum dengan korban. Berapa kerugian material yang diderita akibat tindak pidana tersebut. Kerugian material yang dimaksud merupakan kerugian yang nyata-nyata dapat dihitung dan dapat dibuktikan. Kerugian material tersebut memang belumlah cukup untuk mengganti kerugian immaterial yang diderita oleh korban kejahatan. Akan tetapi, ketentuan tersebut menunjukkan adanya perhatian terhadap pemulihan penderitaan korban akibat tindak pidana.

\section{Penutup}

Keberadaan korban dalam sistem peradilan pidana memang harus mendapat perhatian. Offender oriented yang menjadi karakteristik penegakan hukum sekarang tidak lagi menjamin kepentingan korban yang telah menderita kerugian akibat kejahatan. Posisi korban sebagai pencari keadilan tak lagi mendapat keadilan yang diinginkan. Hal itu disebabkan kepentingan korban tidak ada yang mewakili ataupun memperjuangkan dalam proses berjalannya sistem peradilan pidana. Pemenuhan keadilan bagi korban tidak cukup dengan dipidananya pelaku melainkan harus sampai pada dipulihkannya kerugian penderitaan korban akibat kejahatan yang terjadi.

Posisi jaksa sebagai penuntut umum dalam sistem peradilan pidana sesungguhnya secara hakiki dapat menjadi lembaga yang merepresentasikan kepentingan korban kejahatan. Jaksa melalui kewenangannya melakukan penuntutan terhadap tersangka yang dalam proses sebelumnya telah merugikan kepentingan korban. Dengan demikian penuntutan yang dilakukan merupakan pembalasan terhadap perbuatan sebelumnya terhadap korban. Oleh karenanya akan menjadi lengkap jika dalam melaksanakan kewenangan penuntutan tersebut, jaksa mewakili korban untuk dapat memulihkan kepentingannya baik kepentingan hukum maupun kepentingan dalam hal pemulihan kerugian akibat tindak pidana.

\section{DAFTAR PUSTAKA}

\section{A. Buku}

Bakhri, Syaiful, et al., 2014, Hukum Pidana Masa Kini, Mahupiki dan Total Media, Yogyakarta. Meliala, Adrinus, 2011, Reparasi dan Kompensasi Korban dalam Restorative Jusctice, Lembaga Perlindungan Saksi dan Korban dan Departemen Kriminologi FISIP UI, Jakarta.

Reksodiputro, Mardjono, 2007, Kriminologi dan Sistem Peradilan Pidana, Pusat Pelayanan Keadilan dan Pengabdian Hukum, Jakarta.

Sabuan, Ansorie, et al., 1990, Hukum Acara Pidana, Angkasa, Bandung.

Sapardjaja, Komariah Emong, 2002, Ajaran Sifat Melawan Hukum Materiil dalam Hukum Pidana Indonesia, Alumni, Bandung.
Tahir, Heri, 2010, Proses Hukum yang Adil dalam Sistem Peradilan Pidana di Indonesia, Lakbang Pressindo, Yogyakarta.

Zulfa, Eva Achani, 2011, Restorative Justice dan Peradilan Pro-Korban dalam Reparasi dan Kompensasi Korban dalam Restorative Justice System, LPSK, Jakarta.

\section{B. Artikel Jurnal}

Prayitno, Kuat Puji, "Restorative Justice untuk Peradilan di Indonesia (Perspektif Yuridis Filosofis dalam Penegakan Hukum in Conreto)", Dinamika Hukum, Vol. 12, No. 3, September 2012.

Gunarto, Marcus Priyo, "Sikap Memidana yang 
Berorientasi Pada Tujuan Pemidanaan", Mimbar Hukum, Vol. 21, No. 1, Februari 2009.

Mustofa, Muhammad, "Kehadiran Negara dalam Perlindungan Saksi dan Korban Kejahatan", Jurnal Perlindungan, Edisi 3, Vol. 1, Tahun 2013.

Dunga, Weny Almoravid, "Implementasi UndangUndang Perlindungan Saksi dan Korban di
Gorontalo", Mimbar Hukum, Vol. 21, No. 2, Juni 2009.

\section{Makalah}

Mudzakkir, "Perkembangan Viktimologi dan Hukum Pidana", Makalah, Pelatihan Hukum Pidana dan Kriminologi, Kerjasama FH UGM dan MAHUPIKI, University Club, Yogyakarta, 2014. 